\title{
Mūlācāra 第一章
}

奥 田 清 明

\section{略号：}

v. Glasenapp =H. v. Glasenapp, Der Jainismus, Hildesheim 1964.

Jacobi =H. Jacobi, SBE vol. 45, Delhi-Varanasi-Patna 1964.

“Kunda." 又は K.=“Kundakunda”, Mūlācāra.

$\mathrm{K}^{1}$

$=$ Mū 写真にされたもの。書写の年代は不明であるが, 文字は古 カンナダ文字。各偈に，古カンナダ語による註釈が続く。 表裹の各面は 9-10 行で,一行は約 70 akșaras からなる。 写本は判読しやすい。

$\mathrm{K}^{2}=$ 同じくMūḍbidrī のジャイナ寺院に蔵されている写本。書 写年代は $\mathrm{K}^{1}$ 同様に不明。文字はまた古カンナダ文字。一 つ一つの偈に古カンナダ語の註釈が施される。表寒の各 面は 9 行からなり,一行は約 90 akșaras を収める。Prof.

Alsdorf が写真にされたが，多くの箇所は写りが悪い。

$\mathrm{K}^{3} \quad$ =Nyāytīrth, “Kundakunda”: Mūlācāra+Nyāytīrth の註, Śolapur 1944.

Māc. =Vațțakera, Mūlācāra.

Nyāytīrth. $\quad=\mathrm{s} . \mathrm{K}^{3}$.

Schubring =W. Schubring, Die Lehre der Jainas, Berlin-Leipzig 1935.

Vațț. 又は V. = Vațțakera. s. Māc..

$\mathrm{V}^{1}$

=Vațțakera, Mūlācāra+Vasunandi の註 (Māṇikacandra Digambara Jaina Granthamālā 19+23), Bombay 1921+ 1924.

$\mathrm{V}^{2}$

=Vațțakera, Mūlācāra +Manoharlāl の Hindī 註 (Muni Anantakīrti Digambara Jaina Granthamālā 1), Bombay 1919.

Vasun. $\quad=$ Vasunandi. s. $\mathrm{V}^{1}$. 
空衣派最古の聖典 Mūlācāra は，当時すでに存在していた 12 の texts を寄せ 集め, 1 text を一章とし (計 12 章), 構成されたものである。Māc. には, Vaṭțakera に帰される伝本と，Kundakunda に帰される伝本とがあつて，それらは， その第一章で，ひとしく mūla-guṇas を扱つている。

第 1 章に関して，我々の関心の対象は次の四点である。即ち，(1）mūla-guṇas とは何か，(2) その mūla-guṇas は，白衣派のそれと同じかどらか，(3) 第一章 の基く原本は，白衣派聖典に依存して成立したものか，それとも，空衣派所産の ものか，そして，(4) Vațt. 本と “Kunda.”本では，どちらがオリジナルに近い か,である。

その中，(1）は下の翻訳と註によつて明らかになろら。（2）空衣派の mūlaguṇas が五戒をはじめとする 28 徳 (その名称の列挙は, V.2-3=K. 4-5.) であるのに 対し,白衣派のそれは，五戒（Schubring S. 187），あるいは六戒（二五戒十夜食しな いとと; Schubring, Das Mahānisīha-sutta, Berlin 1918, S. 68) を指すにすぎない。 （3）第一章の原本が空衣派内で成立したといらととは，次の三つの理由によつて 導き出される。即ち，(a）各偈のパラレルが白衣派聖典の中に見い出されない。 （b）主題である mūla-guṇas の内容が，(2) で述べられた通り，白衣派のそれと は別のものである。（c）白衣派の全然知らない khidi-sayana, thidi-bhoyaṇa とい ら概念，及び，白衣派が退けた accelaka が，第一章では説かれている。最後に， (4) Vațt. 本がよりオリジナルに近いととは，K. 2, 3, 18, 40-46 に対する私の註 がそれに答えるであろら。

\section{[テキスト]}

V. 1. mūla-guṇesu visuddhe vandittā savva-sañjade sirasā

K. 1. iha-para-loga-hid' atthe mūla-guṇe kittaissāmi.

K. 2 ṇāṇâdi-rayaṇa-tiyam iha sajjhaṃ, tam sādhayanti jama-ṇiyamā ; jattha jamā sassadiyā, ṇiyamā ṇiyat'appa-parimānāa.

b) ${ }^{\circ}$ dhayantu $\mathrm{K}^{1,2}$; c) ${ }^{\circ} \mathrm{ma}$ jassa ${ }^{\circ} \mathrm{K}^{2}$; d) ${ }^{\circ}$ yat'atta-pa ${ }^{\circ} \mathrm{K}^{1,2}$; ${ }^{\circ}$ riṇāmā $\mathrm{K}^{2}$

K. 3 te mùl'uttara-saṇnā : mūla-guṇā mahav-vadâdi aḍavĩsã tava-parisahâdi-bhedā cottīsā uttara-guṇ’akkhā.

a) mūḷ $u t t a{ }^{\circ} K^{1}$; c) -parisā pi ya bhedā $K^{1,2}$

V. 2,3 pañca ya mahav-vadāiṃ

K. 4,5 pañc' ev' indiya-rohā accelakam aṇhāṇaṃ samidīo pañca jiṇa-var' uddițțā chap pi ya āvāsayā loco

khidi-sayaṇam adanta-ghaṃsaṇam c'eva 
țhidi-bhoyạ̣' eya-bhattạ̣ mūla-gunā ațthavīsā du.

V. $2=K .4$ : a) $-\operatorname{vaya}^{\circ} \mathrm{V}^{1,2} \cdot \mathrm{K}^{3}$; b) ${ }^{\circ} \operatorname{mid} \overline{\mathrm{i} v o} \mathrm{~K}^{2}$; $-\operatorname{varod}^{\circ} \mathrm{V}^{2}$;c) -rodho $\mathrm{K}^{1,2}$

V. $3=$ K. 5 : ācelakkaṃ ṇhā ${ }^{\circ} \mathrm{K}^{1}$, ācela $[\mathrm{kha}] m$ ṇhā ${ }^{\circ} \mathrm{K}^{2}$; c) țiya-bho ${ }^{\circ} \mathrm{K}^{1,2}$;

d) ${ }^{\circ}$ yaṇ'e-bhat ${ }^{\circ} \mathrm{K}^{3}$; mūḷa- $\mathrm{K}^{1}$; ${ }^{\circ}$ vĩṣāṇi. $\mathrm{K}^{1,2}$

V. 4 hiṃsā-viradī saccaṃ

K. 6 sañga-vimuttī ya tahā adatta-parivajjạ̣am ca bambhạ̣ ca

b) bamham $\mathrm{K}^{1,2}$

V. 5 kāyendiya-guṇa-maggaṇa-kulâu-jọ̣īsu savva-jīvāṇam

K. 7 ṇāūṇa ya thāṇâdisu hiṃsâdi-vivajjaṇam ahimsā.

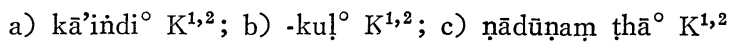

V. 6 rāgâdīhĩ asaccạ̣ cattā para-tāva-sacca-vayạ̣’ uttịm

K. 8 sutt' atthāṇ’ avi kahaṇe ayadhā-vayạ̣’ ujjhaṇaṃ saccaṃ.

a) ${ }^{\circ}$ dīhi $\mathrm{K}^{1,2}$; b) -tāpa-sa ${ }^{\circ} \mathrm{K}^{1,2}$; -uttī $\mathrm{K}^{1,2}$, ${ }^{\circ}$ ṇottim $\mathrm{V}^{2}$; d) ${ }^{\circ}$ yaṇajjha ${ }^{\circ} \mathrm{K}^{2}$

V. 7 gāmâdisu pạ̣idâiṃ appa-ppahudim pareṇa sañgahidam

K. 9 ṇâdāṇam para-davvaṃ adatta-parivajjaṇam tạ̣ tu.

V. 8 mãdu-sudā-bhagiṇ̂va ya daț̣ūṇ’ itthi-ttigam ca paḍirūvam

K. 10 itthi-kahâdi-ṇiyattī tiloya-pujjam have bambham.

a) ${ }^{\circ}$ giṇi vi ya $\mathrm{K}^{1,2}$; b) -ttiyam $\mathrm{V}^{1,2}$. $\mathrm{K}^{3}$; d) tiḷo $\mathrm{K}^{1,2}$; bamham $\mathrm{K}^{1,2}$

V. 9 jīva-ṇibaddhâbaddhā pariggahā jīva-sambhavā c'eva

K. 11 tesim sakka-ccāgo iyaramhi ya ṇimmao' sango.

c) -ccāo $\mathrm{V}^{2} \mathrm{~d}$ ) idaraṃhi $\mathrm{K}^{1,2}$; ṇimmamo' $\mathrm{s}^{0} \mathrm{~K}^{1,2}$

V. 10 iriyā bhāsā esaṇa ṇikkhevâdāṇam eva samidīo

K. 12 padithāivaniyā ya tahā uccārâdīṇa pañcavihā.

c) paițthāvaṇigā $K^{1}$, payațthāvaṇigā $K^{2}$; d) ${ }^{\circ}$ âdīṇi $K^{1,2}$

V. 11 phāsuya-maggeṇa divā jug’ antara-ppehāě sakajjeṇa

K. 13 jantūṇi pariharanten’ iriyā-samidī have gamaṇaṃ.

a) pāsuga- $K^{1}$, pāsuka- $K^{2}$, pāsuya- $K^{3}$; b) juv'an ${ }^{\circ} V^{2}$; -ppehinā $V^{1 \cdot} K^{3}$, -ppehaṇā $\mathrm{V}^{2}$, pekkhiṇā $\mathrm{K}^{1,2}$; c) jantūṇa 全, ${ }^{\circ}$ tūṇi Vasun.; ${ }^{\circ}$ haranti iri ${ }^{\circ} \mathrm{V}^{2}$

V. 12 pesuṇṇa-hāsa-kakkasa-paraṇind' appappasaṃsa-vikahâdī

K. 14 vajjittā sa-para-hidaṃ bhāsā-samidī have kahạ̣aṃ.

b.) ${ }^{\circ}$ ṇindâpappa ${ }^{\circ} \mathrm{K}^{3}$, ${ }^{\circ}$ ṇindâppappa ${ }^{\circ} \mathrm{V}^{1,2}$; c) -hiyam $\mathrm{V}^{1 \cdot} \mathrm{K}^{1,2,3}$; d) kahaṇā $\mathrm{K}^{1,2}$ 
V. 13 chādāla-dosa-suddhạ̣

K. 15 sīdâdī-samabhuttī

kāraṇa-juttaṃ visuddha-ṇava-koḍī parisuddhā esaṇā-samidī.

a) 'dāḷa- $K^{2}$, -suddhim $K^{2}$; b) -koḍim $K^{2}$; c) ${ }^{\circ}$ âdi-ssamabhuttim $K^{2}$;

d) ${ }^{\circ} \operatorname{suddh}[\operatorname{am}] \mathrm{K}^{2}$; -samidim $\mathrm{K}^{2}$; K. 15-21 を, ' $\mathrm{K}^{1}$ は失う。

V. 14 ṇāṇ' uvadhi sañjam' uvadhiṃ sauc' uvadhiṃ aṇna-m-appa-m-uva-

K. 16 payadam gaha-ṇikkhevo samidī ādāna-nikkhevā. dhị̣ vā

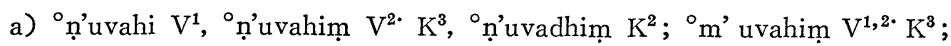

b) ${ }^{\circ}$ c'uvahim $\mathrm{V}^{1,2 \cdot} \mathrm{K}^{3}$;-m-uvahim $\mathrm{V}^{1,2 \cdot} \mathrm{K}^{3}$; c)gahi-ṇikkheo $\mathrm{K}^{2}$; d) -ṇikkeo $\mathrm{K}^{2}$

V. 15

K. 17 egante accitte dūre gūḍhe visāla-m-avirodhe uccārâdi-ccāgo padițhāvaniyā have samidī.

a) ekānte $\mathrm{K}^{2}$; b) visāḷa- $\mathrm{K}^{2}$; ${ }^{\circ}$ rohe $\mathrm{V}^{1,2} \cdot \mathrm{K}^{3}$; c) -ccāo $\mathrm{V}^{1,2 .} \mathrm{K}^{3}$;

d) paițțhāvaṇigã $K^{2}$

K. 18 jiyadu va maradu va jīvo ayadâcārassa ṇicchido bandho payadassa n’'atthi bandho himsā-mettena samidassa.

a) jīvā $K^{2}$; b) ṇicchidā $K^{3}$; hịnsā $K^{3}$; b) samidassa の代りに viradassa $\mathrm{K}^{2}$

V. 16 cakkhū sodam ghāṇam jibbhā phāsaṃ ca indiyā pañca

K. 19 saga-saga-visaehinto ṇirohidavvā sadā munināā.

a) ' hiyavvā $\mathrm{V}^{1,2 .} \mathrm{K}^{3}$; sayā $\mathrm{V}^{1,2 .} \mathrm{K}^{3}$

V. 17 saccittâcittāṇam kiriyā-santhāṇa-vaṇna-bhedesu

K. 20 rāgâdi-saṅga-haraṇaṃ cakkhu-ṇiroho have muninino.

b) -bheesu $\mathrm{V}^{1,2 .} \mathrm{K}^{3}$; c) ${ }^{\circ}$ nga-[h] ha ${ }^{\circ} \mathrm{K}^{2}$ sajjâdi-jīva-sadde vīnâdi-ajīva-sambhave sadde

K. 21 rāgâdīṇa ṇimitte tad-akaranam soda-roho du.

V. 19 payaḍī-vāsaṇa-gandhe
a) sangâ ${ }^{0} \mathrm{~V}^{1 \cdot} \mathrm{K}^{3}$; c) ṇimitam $K^{2}$;
d) -rodho $V^{1,2}$

K. 22 jīvâjīv'appage subhe asubhe rāga-ddosâkaraṇam ghāṇa-ṇiroho muṇi-varassa.

a) pagaḍi- $\mathrm{K}^{1}$, pegaḍi- $\mathrm{K}^{2}$; b) suhe $\mathrm{V}^{1,2 .} \mathrm{K}^{3}$; asuhe $\mathrm{V}^{1,2 .} \mathrm{K}^{3}$; d) ghāṇi-ṇi ${ }^{\circ} \mathrm{K}^{2}$

V. 20 asaṇâdi-cadu-viyappe

K. 23 ițțhânițțhâhāre pañca-rase phāsugamhi ṇiravajje

b) pāsugaṃhi $K^{1,2}$ datte jibbhā-jao' giddhī. 
V. 21 jīvâjīva-samutthe

K. 24 phāse subhe ya asubhe kakkasa-maugâdi-ațtha-bheda-jude phāsa-ṇiroho asammoho.

b) kakkaḍa- $\mathrm{V}^{1,2} \cdot \mathrm{K}^{1,2}$; c) phasse $\mathrm{K}^{1,2}$; suhe $\mathrm{V}^{1,2} \cdot \mathrm{K}^{3}$; subbhe $\mathrm{K}^{2}$; ya 欠 $\mathrm{K}^{1,2}$; asuhe $\mathrm{V}^{1,2 .} \mathrm{K}^{3} ; \mathrm{d}$ ) phassa- $\mathrm{K}^{1,2}$

V. 22' samadā thavo ya vandaṇa pāḍikkamaṇaṃ tah' eva ṇādavvā

K. 25 paccakkhāṇa visaggo karaṇīyâvāsayā chap pi.

a) thao $\mathrm{V}^{2 \cdot} \mathrm{K}^{1,2}$; b) padikka ${ }^{\circ} \mathrm{K}^{3}$, paḍikama ${ }^{\circ} \mathrm{K}^{1,2}$; ${ }^{\circ}$ davvam $\mathrm{V}^{1,2} \cdot \mathrm{K}^{3}$;

d) karaṇîâã ${ }^{\circ} \mathrm{K}^{1,2}$

V. 23 jīvida-maraṇe lābhâlābhe sañjoga-vippajoge ya

K. 26 bandhu' ri-suha-dukkhâdisu samadā sāmāiyaṃ ṇāma.

ab) lāhâlābhe $\mathrm{V}^{2}$, lāhâlāhe $\mathrm{K}^{3}$; sanjoya- $\mathrm{V}^{1,2}$; ${ }^{\circ}$ aoge $\mathrm{V}^{1,2}$; c) bandh'ari ${ }^{\circ}$ $\left.\mathrm{K}^{1,2} ; \mathrm{d}\right)^{\circ}$ mãiyam $\mathrm{K}^{1}$, ${ }^{\circ}$ mãyayam $\mathrm{K}^{2}$

V. 24 usabhâdi-jịnavarāṇaṃ

ṇāma-ṇiruttim guṇậnukittiṃ ca

K. 27 kāūṇa accidūṇa ya ti-suddhi-panamo thavo neo.

a) usahâ ${ }^{\circ} \mathrm{V}^{1,2} \cdot \mathrm{K}^{3}$; d) -suddha- $\mathrm{V}^{2}$; -panamam $\mathrm{K}^{1,2}$; thao $\mathrm{V}^{2 \cdot} \mathrm{K}^{1,2}$ arahanta-siddha-paḍimā-tava-suda-guru-guṇa-gurūṇa rādīṇaṃ kidiyammeṇ' idareṇa ya

ti-yaraṇa-san̉kocaṇam paṇamo.

b) -guṇa-guru-gurū $\overline{0}^{\circ} \mathrm{V}^{1,2 .} \mathrm{K}^{3}$; c) kidikam ${ }^{\circ} \mathrm{V}^{2 \cdot} \mathrm{K}^{1,2}$; ya の代りに va $\mathrm{K}^{1,2}$;

d) ti-kara ${ }^{\circ} \mathrm{K}^{1,2}$; paṇamam $\mathrm{K}^{1,2}$

V. 26

davve khette kāle

bhāve ya kadâvarāha-sohaṇayam ṇindaṇa-garahạ̣a-jutto maṇa-vaca-kāyeṇa paḍikamañam.

a) kāḷ $\mathrm{K}^{1,2}$; b) kayâva ${ }^{\circ} \mathrm{V}^{1} \cdot \mathrm{K}^{3}$, kidâ ${ }^{\circ} \mathrm{V}^{2}$; c) -geraha ${ }^{\circ} \mathrm{K}^{2}$; d) -vaci$\mathrm{K}^{3}$; padikka $\mathrm{V}^{1}$

V. 27 ṇāmâdiṇam chạ̣ham

K. 30 paccakkhāṇam ṇeyam

ajoga-parivajjạ̣aṃ ti-yarạ̣eṇa aṇāgadạ̣ câgame kāle.

a) chaṇnam $\mathrm{V}^{2}$; b) ajogga-pa ${ }^{\circ} \mathrm{V}^{2 \cdot} \mathrm{K}^{1,2}$; ${ }^{\circ}$ ṇam ca ti- $\mathrm{K}^{2}$; - karaṇeṇa $\mathrm{V}^{2 \cdot}$ $\mathrm{K}^{1,2}$; d) ${ }^{\circ} \bar{a} g a y a m \mathrm{~V}^{1,2} \cdot \mathrm{K}^{3}$; kāle $\mathrm{K}^{2}$

V. 28

devassiya-ṇiyamâdisu

jah'uttamāṇeṇa utta-kālamhi

K. 31

V. 29 jị̣a-guṇa-cintaṇa-jutto kā'ussaggo tạ̣u-visaggo.

a) devāsiya- $K^{1,2}$, devasiya- $K^{3}$; ab) ${ }^{\circ}$ su ya thuttamāṇe ${ }^{\circ} K^{1,2}$; b) ${ }^{\circ}$ lamphi $\mathrm{K}^{1,2}$; d) kä'usa ${ }^{\circ} \mathrm{V}^{1}$, kāosa ${ }^{\circ} \mathrm{V}^{2 \cdot} \mathrm{K}^{1,2}$.

K. 32 biga-tiga-caukka-māse sapaḍikkamaṇe divase loco ukkassa-majjhima-jahaṇṇo uvavāseṇ’ eva kāyavvo. 
a) biya-tiya-ca ${ }^{\circ} \mathrm{V}^{1,2} \cdot \mathrm{K}^{3}$; -cadukka- $\mathrm{K}^{2}$; b) ${ }^{\circ} \mathrm{kasa}-\mathrm{K}^{2}$;c) ${ }^{\circ} \mathrm{kkamano} \mathrm{K}^{2}$;

d) 'seṇ'eya $k \bar{a}^{\circ} K^{2}$

V. 30 vatthâjiṇa-vakkeṇa ya

ahavā pattâdiṇā asaṃvaraṇaṃ

K. 33 ṇibbhūsaṇa ṇiggantham accelakkam jagadi pujjam.

ab) ${ }^{\circ}$ ṇa va athavā $\mathrm{K}^{1,2}$; b) ${ }^{\circ}$ âiṇā $\mathrm{V}^{1 \cdot} \mathrm{K}^{3}$; d) āceḷa ${ }^{\circ} \mathrm{K}^{1,2}$; pūjjam $\mathrm{V}^{1,2}$

V. 31 ṇhāṇâdi-vajjạ̣eṇa ya vilitta-jalla-mala-seda-savv'an்gam

K. 34 aṇhāṇam ghora-guṇam sañjama-duga-pālayam muṇiṇo.

a) ṇāṇâdi- $\mathrm{K}^{2}$; b) -malla-se ${ }^{\circ} \mathrm{V}^{2}$; c) aṇāṇam gho ${ }^{\circ} \mathrm{K}^{2}$; d) -pālagaṃ $\mathrm{K}^{1,2}$ V. 32 phāsuya-bhūmi-padese appa-m-asanthāridamhi pacchaṇne

K. 35 dạ̣ụam dhạ̣u vva sejjam khidi-sayaṇaṃ eya-pāseṇa.

a) pāsuga- $\mathrm{K}^{1,2}$; -paese $\mathrm{V}^{1,2 \cdot} \mathrm{K}^{3}$; b) ${ }^{\circ}$ daṃhi $\mathrm{K}^{1,2}$; c) dhanū va $\mathrm{K}^{1,2}$;

d) ekka-pā ${ }^{\circ} K^{1}$, yakka-pā ${ }^{\circ} K^{2}$ an̉guli-ṇahâvalehạ̣i-kalīhĩ pāsāṇa-challiyâdīhị̣

K. 36 danta-malâsohaṇayạ̣ sañjama-guttī adantamaṇaṃ.

a) aṇguḷi- $\mathrm{K}^{1,2}$; b) ${ }^{\circ}$ haṇi-kalim ca $\mathrm{pa}^{\circ} \mathrm{K}^{1}$, ' haṇi-kaṇiṃ ca pā $\mathrm{K}^{2}$; ${ }^{\circ} \mathrm{a} d \bar{h} \mathrm{hi}$ $\mathrm{K}^{1,2}$; c) -malâso ${ }^{\circ} \mathrm{K}^{1}$, -manâaso ${ }^{\circ} \mathrm{K}^{2}$; ${ }^{\circ}$ sohayaṇayam $\mathrm{K}^{2}$; d) ${ }^{\circ}$ tamaḷạ̣ $\mathrm{K}^{1}$, otamamalam $\mathrm{K}^{2}$

a) añjaṇi-pu ${ }^{\circ} \mathrm{K}^{2}$, añjạ̣i-phude ${ }^{\circ} \mathrm{K}^{1}$; b) ${ }^{\circ}$ ḍâi- $\mathrm{V}^{1} \cdot \mathrm{K}^{3}$; -pāyaṃ $\mathrm{V}^{1,2 \cdot} \mathrm{K}^{3}$;

c) parisu ${ }^{\circ} \mathrm{K}^{2}$; -tige $\mathrm{K}^{1,2}$; d) țhiya-bho ${ }^{\circ} \mathrm{K}^{1,2}$; ṇāmam $\mathrm{K}^{2}$

a) kāḷe $\mathrm{K}^{1,2}$; b) ṇāḷ̂- $\mathrm{K}^{1,2}$; -tiya- $\mathrm{V}^{1,2} \cdot \mathrm{K}^{3}$; -vvajidamhi $\mathrm{K}^{2}$, ${ }^{\circ}$ jjiyaṃhi $\mathrm{K}^{1}$; ${ }^{\circ}$ jhamhi $\mathrm{K}^{1,2}$; c) ekkamhi $\mathrm{K}^{1,2}$; dua tie $\mathrm{V}^{1,2} \cdot \mathrm{K}^{3}$, ttige $\mathrm{K}^{2}$; d) muhuta$\mathrm{K}^{2}$; kālega- $\mathrm{K}^{1}$; ${ }^{\circ}$ ega- $\mathrm{K}^{2}$

V. 36 evạ̣ vidhāṇa-jutte mūla-guṇe pāliūṇa tiviheṇa

K. 39 hoūṇa jagadi pujjo akkhaya-sokkham lahai mokkham.

a) vihāṇa- $\mathrm{V}^{1,2 .} \mathrm{K}^{3}$; b) pāḷidū ${ }^{\circ} \mathrm{K}^{1,2}$; c) hodūṇa $\mathrm{K}^{1,2}$; d) lahadi $\mathrm{K}^{3}$; siddham $\mathrm{K}^{1,2}$

K. 40 kāgâmejjhā chaddī jạ̣hū-hițthâmarisaṃ rohaṇa ruhiraṃ ca assu-vādaṃ ca jaṇhuvari vadikkamo c'eva.

a) kākâ ${ }^{\circ} \mathrm{K}^{1 \text { '2 }}$; b) rodhaṇa $\mathrm{K}^{1,2}$; c) -hețțâo $\mathrm{K}^{1,2}$; 
d) ${ }^{\circ} \mathrm{ri} \operatorname{madi}^{\circ} \mathrm{K}^{1}$ ；乙の偈をはじめとする七偈は，V. 本では第六章に現われる。

K. 41 ṇābhi-adho-ṇiggamaṇaṃ

kāgâdi-piṇḍa-haraṇaṃ paccakkhida-sevaṇā ya jantu-vadho pāṇīdo piṇḍ-paḍaṇam ca.

b) ${ }^{\circ}$ kkhiya- $\mathrm{V}^{1,2} \cdot \mathrm{K}^{3}$; ${ }^{\circ}$ tu-vaho $\mathrm{V}^{1,2} \cdot \mathrm{K}^{3}$; kākâ ${ }^{\circ} \mathrm{K}^{1}$

K. 42 pāṇīe jantu-vadho maṃsâdì-damsaṇe ya uvasaggo pād'antarammi jīvo sampādo bhājaṇāṇaṃ ca.

a) ${ }^{\circ}$ niiye $\mathrm{K}^{2}$; -vaho $\mathrm{V}^{1,2} \cdot \mathrm{K}^{3}$; b) māmsâ ${ }^{\circ} \mathrm{K}^{2}$; c) ${ }^{\circ}$ tara-pan̉khim ya jīo $\mathrm{K}^{1}$, ${ }^{\circ}$ tara-pankkhim vi ya $\mathrm{ji}^{\circ} \mathrm{K}^{2}$; d) sampāta $b \bar{a}^{\circ} \mathrm{K}^{1}$, sampāsadam bhā $\bar{a}^{\circ}$ $\mathrm{K}^{2}$; bhāyaṇā ${ }^{\circ} \mathrm{V}^{1,2} \cdot \mathrm{K}^{3}$

K. 43 uccāraṃ passavaṇaṃ abhojja-giha-pavěsaṇaṃ tahā paḍaṇaṃ uvavesaṇam sadamsam bhūmī-samphāsa ṇițthuvaṇam.

b) abhoja-gi ${ }^{\circ} \mathrm{V}^{1,2 \cdot} \mathrm{K}^{1}$, bhoja-gi ${ }^{\circ} \mathrm{K}^{2}$; -giha-bhojaṇam $\mathrm{ta}^{\circ} \mathrm{K}^{1,2}$; paḍaṇa $\mathrm{V}^{1}$; c) sadamsī $\mathrm{K}^{1,2}$; d) -sampāsa $\mathrm{K}^{1}$; ṇițthava ${ }^{\circ} \mathrm{K}^{3}$

K. 44 udara-kkimi-ṇiggamaṇam adatta-gahaṇaṃ pahāra gāma-daho pādeṇa kiñci gahạ̣aṃ kareṇa vā jạ̣ ca bhümīe.

b) ${ }^{\circ}$ haṇam ca pahā ${ }^{\circ} \mathrm{K}^{1,2}$; ${ }^{\circ}$ ma-ḍaho $\mathrm{V}^{1,2} \cdot \mathrm{K}^{2,3}$; d) jạ̣ ca の代りに kiñ ci $\mathrm{K}^{1,2}$; ${ }^{\circ}$ mide $\mathrm{K}^{1,2}$

K. 45 ede aṇne bahugā bīhaṇa-loga-duguñchaṇě kāraṇa-bhūdā abhojaṇassehā sañjama-ṇivvedaṇ'ațtham ca.

a) bahukā $\mathrm{K}^{1,2}$; b) abhoya ${ }^{\circ} \mathrm{V}^{1,2}$; c) ${ }^{\circ}$ sseha 全; c) ${ }^{\circ}$ chaṇa 全

K. 46 ṇaha-roma-jantu-ațțhì bīya-phala-kanda-mūlam kaṇa-kuṇ̣aya-pūya-camma-ruhiram ca mamsaṃ ca malā du coddas' ime.

K. $46=$ K. $6.65=$ V. 6. $65:$ b) ${ }^{\circ}$ ḍaya-pūyi (-pūya $\mathrm{K}^{3}$ 1.46)-camma-ruhiramaṃsāṇi $\mathrm{V}^{1,2}$, ${ }^{\circ}$ ḍaya-ruhira-māṃsa-cammāṇi (-camāṇi $\mathrm{K}^{2}$ ) $\mathrm{K}^{1 ’ 2} 1.46$; c)

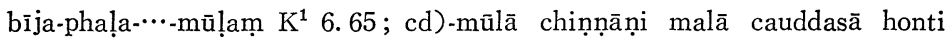
$\mathrm{V}^{1,2 \cdot} \mathrm{K}^{3} 1.46$, phaḷa-mūḷa-kanda-bījạ̣ chiṇnāṇi coddasā honti $\left.\mathrm{K}^{1,2} 1.46 ; \mathrm{d}\right)$ māṃsạ̣ ca maḷā $\mathrm{K}^{1} 6.65$; coddasame $\mathrm{K}^{3} 6.65$; アルスドルフ教授が $\mathrm{K}^{2}$ 第 56 葉目以後を写真にされなかつたので, $\mathrm{K}^{2} 6.65$ は参照不可能。

\section{[訳と註]}

V. 1 基本的な徳によつて (その霊が) 浄められた全ての出家に, 頭をもつて 礼して，ての世とあの世の安寧をもたらす基本的な徳を説てら。

K. 2 さて, 知識などの三宝1) ${ }^{1)}$ 得られるべきものであり, yamas ${ }^{2)}$ と niyamas $\left.^{3}\right)$ が，それを得させる。その中で，yamas は常に（守ら 
れるべきものであり), niyamas は（その)継続時間が定められて いて，短 [時（また，期）間行われるもの]である。

K. 3 基本的な (徳) と（それに）続く（徳）の名称: mahā-vratas など の二十八4)が，基本的な徳であり，苦行 (の十二種5) ${ }^{5}$ ) と辛苦の忍 耐 (二十二) 種6) (の，合計) 三十四が，(それに) 続く徳と称する。

1 知識（jñāna）と信仰（darśana）と出家の実践（cāritra）をいう。

2 Nyāytīrth: mahā-vratâdik.

3 同上: sāmāyik (=sāmāyika. s. Schubring § 170 etc.), pratikramaṇ (=pratikramana. s. V. 26.) 等。Śvet.s の niyamas については, v. Glasenapp. S. 377.

4 V. 2 及び 3 で列挙され, 詳しくは, V. 4 以後で解説される。

5 苦行は, 大きく (a) 内的苦行 (abbhantara-tava) と (b) 外的苦行 (bāhira-tava) に分けられ，(a)，(b) はさらに，それぞれ六種類に細分される。即ち，(a) は, (1) 贖罪 (pāyacchitta), (2) 善い態度 (末た, 行為: viṇaya), (3) 助力 (vejjāvacca), (4) 学習 (sajjhāya), (5) meditation (jhāṇa), および (6) 放棄 (viussagga）がらなり，（b）は，(1) 断食 (aṇasaṇa)，(2) 減食 (omodariya)，(3) 美食の放妄 (rasa-paricāya)，(4)（家，施者，容器，食べ物に関する乞食上の） 規則の厳格化（vutti-parisankhāa)，(5) 肉体を苦しめること (kāyassa paritāva), および（6）(女神や婦人や動物の䧳から）離れた卧, 座所（を利用すること） (vivitta-sayaṇâsaṇa) からなる。s. Māc. 5. 163 \& 149.

6 s. Schubring $§ 176$ \& Jacobi p. $9 \mathrm{ff}$.

K. 2 は yamas と niyamas を説明し, K. 3 は mūla-guṇas と uttara-guṇas の細 目を挙げている。とてろで，V. ld=K. ld は “mūla-guṇe kittaissāmi” と約束し ている。との言葉から我々は，次の偈に mūla-gunas の名称列挙か，その説明を期 待する。しかるに，K. 2 は主題を離れ，K. 3 は約束以上のてとにまで言及してい る。 V. ld=K. ld の約束に答えるものは，やつとK .4=V. 2 になつて現われる。 即ち, K. 2 と 3 は後世の挿入物である。

V. 2,3

K. 4,5

ジナ王たちによつて説かれた，二十八の基本的な徳は，五つの大戒（を 守るとと） [1-5；s. V. 5-9]，五つの用心（をするとと）[6-10；s. V. 10-15]，五つの，感官の制御（を行らとと）[11-15；s. V. 16-21]，六 つの āvaśyakas（を行らとと） [16-21；s. V. 22-28]，抜毛すること[22； s. V. 29], 裸でいるとと [23; s. V. 30], 洙浴しないとと [24; s. V. 31]，地面に寝ること [25；s. V. 32]，歯を磨か妨とと [26；s. V. 33]， 立食するとと [27；s. V. 34]，および一（定時間に）食（事するとと） [28； s. V. 35] である。 
V. 4 五つの大戒とは, (次のものだと) 説かれている。(即ち), 殺生しない こと〔1]，真実（を語るとと）[2]，与えられてない物は避けるとと [3]， 貞潔（を守るとと）〔4]，および所有を離れるとと〔5]（である）。

V. 5 生き物それぞれが，(いかなる）身体 (をもち1)，(いくつの）感官（を 有し2) $\left.{ }^{2}\right)$ (どの) 徳位 (にあり3) , (どの点に関して) 調 (べられ4) , (どの) 種（に属し), (どのくらいの) 寿命 (をもち), (どこを) 発生 場所 (とするか5) を知り，立つている(場合）など6において，殺生 などを避けるととが，不殺生である。

1. Vasun.: kāyāh-prthivyap-tejo-vāyu-vanaspati-trasāḥ, tātsthyāt sāhacaryād vā prthivī-kāyikâdayaḥ kāyā ityucyante.

2 同上: indriyāṇi pañca-sparśana-rasana-ghrāṇa-cakṣuh-śrotrāṇi. ekaṃ sparśanam indriyam yeșām te ekendriyāḥ. $\cdots \cdot$. pañca sparśana-rasana-ghrāṇacakṣuḥ-śrotrāṇindriyāṇi yeṣãm te pancendriyāḥ.

3 その霊が，完全にカルマに支配されている状熊から，カルマを全く離れた状態 まで，その段階を十四に分ち，ある生を物が，ど段階にあるかを問うもので ある。詳しくは, s. v. Glasenapp S. 195ff.

4 調查点は 14 ある。即ち, Vasun. によると, gati, indriya, kāya, yoga, veda, kaṣāya, jñāna, saṃyama, darśana, leśyā, bhavya, samyaktva, sañjñā と āhāra である。

5 Vasun.: jīvotpatti-sthānāni-sacittâcitta-miśra-śītoṣṇa-miśra-saṃvṛta-vivṛtamiśrāni.

6 同上: sthānâsana-śayana-gamana-bhojanodvartanâkuñcana-prasāranâdi-kriyāviśeșeșu.

V. 6 欲などに (駆られて 8 ) ) 語る偽や，真実ではあるが他を傷つける言葉を 喋るとと2)を避け，経典を伝え真理を説く場合に，間違つて語るととの ないととが，真実（を語るとと）である。

1 Vasun.: rāga-dveșa-mohâdibhị̣ paiśūnyerṣyâdibhiś ca.

2 Mäc. 5. 116 に対するVasun. によると，もし，ある盗人が逃げていくのを見 て，追跡してきた巡查に「盗人を見たか」と聞かれたら，『いいえ』と答えると とが，高い意味での真実である。すなわち，もし『はい』と答えたら，盗人は 捕えられ，罰せられるであろう。『いいえ』と答えることは，盗人を罚から救う ことになる。前者は, 真実ではあるが, 他を傷つける言葉であり，後者は，偽 ではあるが, 人を救う言葉である。ジャイナ教では, 前者は禁ぜられ, 後者が 積極的に奖められている。

V. 7 (それが) 少量であれ…1), 村などに落ちている…2), 他人が集めた他人 の物を取得しないととが，与えられたものでない物は避けるということ 
である。

1 Vașun.: stoka-bahu-sūkṣma-sthūlâdīni.

2 同上: patita-nașța-vismṛta-sthāpitâdīni.

V. 8

K. 10 （老女，少女，及び若い婦人といら）三種（に分類された）女や（上の三 種の女の）像を，(老女の場合）母, (少女の場合) 娘, (若い婦人の場 合）妹と視て，女への（優しい）語らいなどをしないとと妾が，三世に 敬われる貞潔である。

1 Vasun.: vanitā-komalâlāpa-mṛdu-sparśa-rūpâlokana-nṛtya-gīta-hāsa-kațākṣanirīkṣaṇâdyanurāga-tyāgaḥ.

V. 9 K. 11 生き物に関連したもの ${ }^{1)}$, 関連しないもの 2 ，および生き物から現われ 出たもの3)，乙れらを力の限り放衰し，また（これら）以外のものに4) も所有意識を起さぬ（こと）が，所有を離れるととである。

1 Vasun.: deha-mithyātva-veda-rāga-hāsya-ratyarati-śoka-bhaya-jugupsā-kro dha-māna-māyā-lobhâdayaḥ.

2 同上: kṣetra-vāstu-dhana-dhānyâdayaḥ.

3 同上: muktā-phala-śankha-śukti-carma-danta-kambalâdayaḥ.

4 同上: saṃyama-jñāna-śaucopakaraṇeșu.

V. 10 用心は五種類である。(即ち)，歩行や言葉や行乞（の用心）[1-3]，（物 を）置いたり，手にする（際の用心）[4]，および大便等をおろす1)(場 合の用心である) [5]。

1 Dig. s は, とのように上品な表現をする。Śvet. s は, ただ “uccāre”とのみ記 す。

V. 11 . 生きもの (また, 生命)を含まぬ道1)を[1], 昼 [2], 一ユガ (内) を 視つつ [3]，（正しい）動機2)をもつて[4]，生きものを避けながら行く ことが，歩行の用心である。

1 phāsuya-magga は，いろいろな車や諸々の動物や多くの人々が行ったり，太陽 熱で焼かれていたり，鋤などの道具で掘り返されたりしている道をいら。 s. V. 5. 107-109.

2 Vasun.: prayojanaṃ śāstra-śravaṇa-tīrtha-yātrā-guru-prekṣaṇâdikam.

V. 12 中. 中傷，揶揄，暴（言），非難，自己称讃，および無益な話1)を避け，自分 と他人の為になる2)話をするととが，言葉の用心である。

1 具体的には, Vasun. によると, strī-kathā, bhakta-kathā, caura-kathā, rājakathā 等。

2 Vasun.: ātmano' anyasya ca sukha-karaṃ karma-bandha-kāraṇa-vimuktam. 
V. 13 四十六の罪過1)を離れ，(食べる）理由があり2)，九つの場合が各なく3), 冷い（かどらか）などに無関係に食べること4)が，行乞の正しい用心で ある。

1 Māc. 第 6 章では, 行乞の 47 の罪過が解説されている。即ち, 施者の過失 (uggama) と受者の過失 (uppādaṇa) が各 16, 受ける際の過失 (esaṇā) が 10, 施 物を混ぜ合わす過失（sañjojaṇā)，量（を越す）過失（pamāṇa），おいしいも のをまた食べたいといら願いをもつて食べる過失（ingāla），まずいものを文句 を言いながら食べる過失（dhūma），おょび理由（なく）食べる過失（kāraṇa） が各一, 合計四十七が説明されている。てれらの中, 最後の過失は, 我々の偈 では別個に書かれているので，47 の罪過という表現は現われず，chādāla-dosaと言われるのである。

2 Vasun.: asāto*daya-jāta-bubhukṣā-pratīkārârthạ̣ vaiyāvṛttyâdi-nimittam ca. また, Piṇ̣̂aniryukti 662キMāc. 6.60:

veyaṇa-veyāvacce iriy' ațthāe ya sañjam' ațthāe taha pāṇa-vattiyāe chațtham puṇa dhamma-cintāe.

b) kiriyâțțhāe ya sañ ${ }^{\circ}$ Māc.; cd) tadha pāṇa-dhamma-cintā kujjā edehĩ āhāraṃ Māc.

（飢えの）苦痛（を鎮める）ため（ācāryasなどに）仕えるため，歩行の用心 （をする）ため[Dig. s: (āvaśyakasを) 行なうため], 自制するため，生命保 持のため，および第 6 番目に， dharma を思考するため。

* s. v. Glasenapp, Die Lehre vom Karman in der Philosophie der Jainas, Leipzig 1915, S. 23.

3 同上: mano-vacana-kāya-kṛta-kāritânumati-rahitam.

4 同上: śĩtoṣnâdiṣu bhakṣyeșu rāga-dveșa-rahitatvam.

V. 14

K. 16

(聖典) 知 (獲得) のための用品1)，自制（する）ための用品)，（尻を） 清潔（化する）ための用品3)，および（その）他の，身体のための用品4) を，注意深く手にしたり，置いたりすることが，(物を）手にしたり， 置いたりする際の用心である。

1 Vasun.: pustaka 等。2 同: picchikā 等。

3 同上: kuṇ̣ikā 等。 4 Nyāytīrth : cațāī, phalak, tṛn 等。

V. 15

K. 17

人里離れた，生き物の居ない（村などから）遠い，人目につかぬ，広 がりを有する（人の）各めのない（場所）に，大便などを捨てること が，(大便などを）おろす（際の）用心である。

K. 18 生き物が生きていようと，死のうと，(自分の）行為を制さぬ ものは，確実に業を結ぶ。(行為を）制し，用心しているもの は，殺生（を行つた）だけでは（業を）結ぶことはない。 
この奇妙でェゴイステックな内容を持つ偈は, “Kunda”が Pavayanasāāra 3.17 （1-2）加ら採用し，ててに挿入したものと思われる。なお，との偈は K. 5.245 としても現われるが，その場においても適さない。

V. 16

K. 19

目，耳，鼻，舌，および皮膚は五官である。出家は，(これらを）てれ ぞれの対象から遠ざけるべきである。

V. 17

K. 20

生き物や非生物の（いろいろな）種類の動き1)や形2)や色3)に関して， (快いものに対しては) 愛情 (不快なものに対しては嫌悪, ) 等の感情 (sanga：執着）を起さぬととが，出家の「目の制御」である。

1 Vasun.: gīta-vilāsa-nṛtya-cańkramaṇâtmikā.

2 同上; sama-caturasra-nyagrodhâdyātmakạ̣ vaiśākha-bandha-puṭâdyātmakam ca.

3 同上: gaura-śyāmâdayah.

V. 18

K. 21

V. 19

K. 22

V. 20

K. 23

V. 22

K. 25

V. 23

K. 26

V. 24

K. 27

愛情などを起させる，音階第一音など生き物の声や，ヴィーナなど非生 物の音を。それらに関わらないととが，耳の制御である。

(それが) 生き物のものであれ，非生物のものであれ（それが）快いも のであれ，不快なものであれ，(それ）自身の香りや董習(された）香り に，愛憎を起さないととが，出家王たちにとつて，鼻の抑制である。

主食等の四区別1)があり, 五味 ${ }^{2}$ )を含み, 生命 (また, 生きもの) を有さ ぬ，各のない食事が与えられた時，(それが）おいしいものであれ，ま ずいものであれ，(それに）無頓着であるととが，舌の抑制である。

1 四区別とは，(a) asaṇa，(b) pāṇa，(c) khāima，及び（d） sāima である。 Nyāytīrth によると, (a) は, bhāt, roțī, pūrī 等; (b) は, dūdh, khīr, rabḍīi (c) は, peḍhā 等; (d) は, ilāycī, lavañg 等である。

2 Vasun.: tikta, kațu, kașāya, āmla, madhura.

V. 21 生物や非生物に生じる, 粗い, 柔い等の八種の感触1)が，快いものであ れ，不快なものであれ，(それに）惑わないことが，皮膚の制御である。

1 Vasun.: karkaśa, mṛdu, śīta, uṣna, snigdha, rūkṣa, guru, 及び laghu.

(以下の) 六 āvaśyakas が行われるべきだと知るべきである。(即ち),

（i）平静, (ii) 讃美, (iii) 礼, (iv) 懺悔告白, (v) 回避, および（vi） 放衰（である）。

生や死, 取得や不取得, 出会いや別離, 友や敵, 楽や苦などに平静であ るととが，平静といらことである。

Rṣabha などジナ王たちの名の由来を語り，（彼らの）徳を称え，(彼ら 
を）祭り（彼らに）三つの清浄をもつて1)礼することが，讃美であると 知るべきである。

1 Vasun.: mano-vāk-kāya-śuddhibhih.

V. 25

K. 28

arhats の像, siddhas の像, および苦行や聖典（知）や深い徳を具えた, 法臘の長い師に，kiikamma1)と（それ）以外の ${ }^{2)}$ (礼をするとと）によ つて，三器官を収斂するととが，礼である。

1 Vasun.: kāyotsargâdikeṇa siddha-bhakti-śruta-bhakti-guru-bhakti-pūrvakeṇa. また, E.Leumann, Übersicht über die Āvaśyaka-Literatur, Hamburg 1934, S. 10 b.

2 同上: śruta-bhaktyâdi-kriyā-pūrvakam antareṇa śiraḥ-praṇāmena muṇ̣̣avandnaayā.

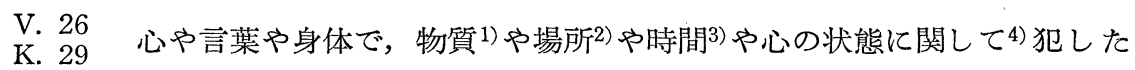
罪を，懺悔告白し，浄めることが，懺悔告白である。

1 Vasun.: āhāra-śarīrâdi-vișaye.

2 同上: vasatikā-śayanâsana- gamanâdi-mārga-vișaỳe.

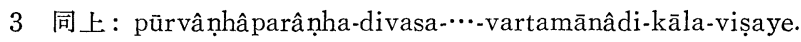

4 同上: pariṇāme - citta-vyāpāra-viṣaye.

V. 27 名（付け）など六つに関する1)䛊つた（行為）を，未来と現在に（身口 意の）三において避けるととが，(罪の）回避であると知るべきである。

1 Vasun:: nāma-sthāpanā-dravya-kṣetra-kāla-bhāvānām. nāma 等に題しては, Schubring § 77 を見よ。

V. 28 昼の niyama 等において 31 , 教えられた時刻に, 定められた時間 2 , , ナたちの徳を考えつつ kāyotsarga（直立不動の姿勢）をとることが，身 体の放衰である。

1 Vasun.: daivasika-rātrika-pākṣika-cāturmāsika-sāṃvatsarikâdiṣu niyameṣu niścaya-kriyāsu.

2 同上: pañcaviṃśati-saptaviṃśatyașțottara-śatâdyucchvāsa-parimāṇena.

V. 29 二，あるいは三，あるいは四ケ月 (が終わる前後1) ${ }^{1)}$ に，昼，笺悔告白 と断食を行つて，(二ケ月が終わる前後には）最高の（三ケ月が終わる 前後には）中級の，そして（四ケ月が終わる前後には）最低の抜毛2)が 行われるべきである。

1 文字通りには，「二，あるいは三，あるいは四ヶ月に」であるが，Vasun.に従 つて上のように訳した。

2 抜毛は, Vasun. によると, 頭髮だけでなく, 髭もその対象である。抜毛する根 拠は, Vasun. によると, jīva-sammūrcchanâdi-parihārârthaṃ rāgâdi-nirāka-

$$
-1048-
$$


raṇ̂rrthaṃ svavīrya-prakațanârthạ̣ sarvotkṛșța-tapaś-caranârthạ̣ lingâdiguṇa-jñāpanârtham ceti である。

V. 30

布や毛皮や樹皮や葉などによつて（身体を）覆わないとと，装身具（を 身に着け）ないとと，および所有物を持たないとと吕が，世に敬われる ベき裸形である。

1 Vasun.: granthebhyah samyama-vināśaka-dravyebhyo nirgatam nirgrantham : bāhyâbhyantara-parigrahâbhāvaḥ. なお abbhantara-ganthas (=a.-parigrahas) は, “Kunda” 5. 232 によると, 怒り (koha), 高慢 (māṇa), 迷い (māyā), 貪 り (loha), 愛情 (rāga), 憎しみ (dosa), 邪信 (micchatta), 性行為 (veda), 意 欲 (radi), 無気力 (aradi), 笑い (hāsa), 嘆き (soga), 恐れ (bhaya), おょび 嫌悪 (dugguñchā) であり, bāhira-ganthas (=b.-parigrahas)は, “Kunda” 5 . $233=$ Vatṭ. 5. 211 にると畑 (khetta), 家 (vatthu), 貴重品 (dhana), 穀物 (dhaṇna), 二本足のもの (duppada), 四つ足のもの (caduppada), 乗り物 (jāṇa), ベット (sayaṇa), 座椅子 (āsaṇa), おょび金属 (kuppa) である。

V. 31 沐浴などを避けるとと1)により，全身が全身的な污 ${ }^{2)}$ と部分的な励3)と汗 で污れることが，出家の不沐浴で，(それは）勝れた徳を有し，二種の 自制を守るもの4)である。

1 Vasun. によると, snāna の他, udvartana, añjana, jala-seka, tāmbūla-lepana などを避けるとと。

2 Vasun.: jallaṃ—sarvânga-pracchādakam.

3 同上: malaṃ一añgaikadeśa-pracchādakam.

4 同上: indriya-saṃyama -prāṇa-saṃyama-rakșakam. indriya-saṃyama は, 六官の制御であり，prāṇa-samyana は，14の生きものに対する自制である。な お, 14 の生きものについては, R. B. J. L. Jaini, Nemicandra : GommațasāraJĩvakaṇḍa, Lucknow 1927, p. 54. をみよ。

V. 32 生きもののいない, 隠れた ${ }^{1)}$ 場所に, 敷物を全然敷かず2), 杖や弓の形に 横卧するとと年が，地面に寝ることである。

1 Vasun.: pracchanne-guptaikapradeśe strī-paśu-ṣaṇḍaka-vivarjite asaṃyatajana-pracāra-vivarjite.

2 蓋然性にしたがつて訳した。Vasun. も理解に苦しみ, 次の四つの可能性を捉し ている。即ち, appamasanthāridamhi: (1) alpam api stokam api asanstaritam aprakșiptam yasmin so 'lpâsaṃstaritas, tasminn alpâsaṃstarite; (2) alpavati samstarite yena bahu-saṃyama-vighāto na bhavati, tasmin tṛnamaye kāṣthamaye bhūmi-pradeśe ca saṃstare gṛhastha-yogya-pracchādana-virahite; (3) ātmanā vā saṃstarite nânyena; (4) ātmānaṃ mimīta iti ātmamạ̣ ātmapramāṇaṃ saṃstaritam cāritra-yogyaṃ tṛnâdikaṃ yasmin sa ātmama-saṃstarita-pradeśas, tasmin. 


$$
\text { Mūlācāra 第一章（奥－田） }
$$

3 Vasun.: adho mukhenottānena śayyā na kartavyā, doṣa-darśanāt.

V. 33

指，爪，楊枝，kali1)により（また）石や樹皮などにより，歯垢を取り 除かぬことが，歯を浄めぬことであり（それは感官の）制御を守るも のである。

1 Vasun.: tṛna-viśeṣah.

V. 34

K. 37

壁など（に凭れること）なく, 生き物（また，生命）のいない三つの場 所 ${ }^{1)}$ に，足を平行にして立ちつつ，手の鉢で食べるてとが，立食である。

1 Vasun.: svapāda-pradeśotș̣șța-patana-pariveșaka-pradeśe.

V. 35

K. 38

V. 35

K. 39

日の出と日没の各三 nāḍis を避けた，（日）中の一 muhūrta か二 muhūrtas か三 muhūrtas に（食事することが），一（定時間に）食（事す るとと)である。

このよらな $\left(28\right.$ の) 種類をもつ基本的な徳を三様に ${ }^{1)}$ 行えば，世間に敬 まわれるものとなり，不壊の安寧である解脱を得る。

1 Vasun.: manasā vacasā kāyena vā.

K. 40 （次の場合, 食事することが中止される。即ち，）(1)(出家が食 事のため出向いている時や食事のために立つている時, )烏 (な どの鳥）が(出家の身体に霬を落した場合)，(2) 不潔な物（に よつて足などが㛂れた場合)，(3) 嘔吐した場合，(4)(「君は食 事に行つてはならない」等と言つて), 制止 (した場合)，(5) （自分や他人の）血が（身体から出，四指幅まで流れたのを見 た場合 (a)，(6)（悲しみの故に，自分や他人の目から）涙が流 れ落 (ちた場合)，(7) 膝から下に(手が) 触（れた場合），(8) 膝から上で罪めが(犯された場合),

K. 41 (9) 膝より下に（頭をして，食事に）行( (かねばならぬ場合)， (10捨てられたものを食 (べた場合)，(11)（目の前で，猫が鼠を 殺すといつた）生き物の殺害が（行われた場合），(12)鳥などが （手から）一塊の食べ物を奪い去（つた場合），13 手から一塊 の食べ物が落（ちた場合）,

K. 42 (14) 手 (の鉢) による生きものの殺害が (あつた場合(d), (15) 肉 などが見られた場合，(16)（食事時，神や人や動物の）攻撃が (あつた場合)，17（食事時）両足の間を生き物が（通つた場 合)，18（施者の手から）鉢が落 (ちた場合), 
K. 43 (1920（食事時））大便や小便が（排泄された場合），(21（その家 の食事が）食べてはなら家に入（つた場合），22（目矓など して）倒（れた場合），(23）座（つた場合）（24（犬，猫などに） 嚙まれた（場合），(25）地に（手が）触（れた場合），(26（痰な どを）吐（いた場合）,

K. 44 (27) 腹から虫が出て来 (た場合), (28) 与えられてないものを得 (た場合), (29) (自分や他人に) 暴力が (振われた場合)，(30) 村 に火事が（あつた場合），(31122）足や手により，地面から何かを 拾（い上げた）場合。

K. 45 これら（32 の場合）や他の多くは®(食事をしない) 原因であ る。食事をしたくないといら気持は，(王の）迫害や人々の反 感（があつても），自制や世俗への嫌悪から（実行に移される）。

K. 46 爪, 毛, 動物 (の死体), 骨, (大麦, 小麦などの) 粐殼, (米 などの）糠，膿，皮膚，血，種子，果実，株，根，および肉， これらは 14 の不浄物である。

(a) Nyāytīrth: Is se kam bahne par antarāy nāhĩ hẽ.

(b) とういう罪?

(C) この姿勢の現実性?

(d) Vasun.: jantur ātmanâgatya pāṇau bhuñjānasya yadi mriyate.

(e) 同上:caṇụālâdi-sparśa-kalaheșța-maraṇa-sādharmika-sanyāsa-patana-pradhāna-maraṇâdayaḥ.

K. 40-46 は, “Kunda.”が挿入したものである。何故なら，(1)V. $36=K .39$ は明らかに結びの偈であり，この章はこの偈でもつて 終つていることを示す。(2)もし，V. 36=K. 39 を結びの偈でない と許した場合, 我々は, K. 46 の次に, 他の 11 章にならつて, 結 びの偈を予期するが，それが現われない。ということは，やはり V. 36=K. 39 が結びの偈であつて, K. 40ff は付加物である。(3) K. 40ff. の内容は, mūla-gunas と無関係である。(4)その内容は, V. 本におけるように, むしろ第 6 章「Piṇda-śuddhi」において適 する。即ち, “Kunda”は, 40ff. をV. 6.76-81および 65 から得 たのである。 